DOI: http:/ / dx.doi.org/10.30747/bfgez.66.2016.04

\title{
Z BIBLIOTEKI FUNDACJI
}

Aleksandra Rybińska, Rola, działalność i znaczenie kobiet w Armii Krajowej. Wybór biografii regionu tódzkiego, Biblioteka Fundacji „Archiwum Pomorskie Armii Krajowej", Torun 2016, ss. 158

Nakładem Biblioteki Fundacji ukazała się niezwykle interesująca i ważna książka poświęcona służbie kobiet w szeregach Armii Krajowej (AK), służbie, która wciąż jest nieco pomijanym i nawet zapomnianym fragmentem dziejów Polskiego Państwa Podziemnego. A kobiety stanowiły ok. $10 \%$ stanu osobowego AK. Autorka za cel postawiła sobie przedstawienie biogramów kilkunastu kobiet z AK regionu łódzkiego, które do tej pory nie były nigdzie publikowane. Poprzedziła to przedstawieniem genezy służby kobiet $\mathrm{w}$ formacjach wojskowych od zakończenia I wojny światowej aż do końca II wojny światowej.

Książka składa się z czterech rozdziałów, ułożonych tematycznie. W rozdziale pierwszym zatytułowanym Kobiety-żotnierze $w$ Wojsku Polskim 1918-1945 autorka opisuje najważniejsze kobiece organizacje wojskowe czyli Ochotniczą Legię Kobiet (OLK) i Przysposobienie Wojsko- 
we Kobiet (PWK), które wpłynęły na późniejsze zaangażowanie kobiet $\mathrm{w}$ działalność konspiracyjną w czasie wojny. Ponadto przedstawia losy kobiet walczących w kraju w ramach SZP-ZWZ-AK oraz na Wschodzie (Armia gen. W. Andersa, 2. Korpus Polski) i na Zachodzie (Pomocnicza Służba Kobiet we Francji i Anglii).

Rozdział drugi pt. Kobiety w stużbach łączności w Wojsku Polskim 1918-1945 składa się z trzech podrozdziałów: Wojska łączności w latach II Rzeczypospolitej; Rola kobiet w tączności w szeregach SZP-ZWZ-AK oraz Obstuga technicznych środków taczności przez kobiety w okresie konspiracji. Poświęcony jest pracy kobiet w łączności wojskowej, w której - wbrew panującym stereotypom, że kobiety to tylko sanitariuszki i łączniczki - odgrywały znaczącą rolę. Niestety ze względu na brak dostatecznej liczby opracowań i źródeł rozdział ten jest najskromniejszy.

Kolejny rozdział przedstawia działalność kobiet w służbie zdrowia. Zatytułowany Kobiety a stużba zdrowia w Wojsku Polskim 1918-1945 podzielony został na następujące podrozdziały: Cywilna stużba zdrowia w II Rzeczypospolitej; Wojskowa stużba zdrowia w II Rzeczypospolitej oraz Organizacja stużby zdrowia w SZP-ZWZ-AK. Autorka celowo rozdzieliła w okresie międzywojennym służbę medyczną na pion cywilny i wojskowy, ponieważ kobiety pracowały głównie w zawodach cywilnych, a z wojskową służbą medyczną tylko współpracowały w ramach organizacji społeczno-charytatywnych np. Polskiego Czerwonego Krzyża. W Drugiej Rzeczypospolitej nie było lekarki ze stopniem wojskowym.

I ostatni rozdział Łącznicz$k i$, sanitariuszki, zotnierki - sylwetki kobiet - biografie regionu tódzkiego, który jest podzielony na 15 podrozdziałów - każdy $\mathrm{z}$ nich to biogram kobiety-żołnierza AK rejonu łódzkiego. Część biogramów została opracowana na podstawie wywiadów przeprowadzonych przez autorkę z żyjącymi jeszcze uczestniczkami lub ich krewnymi, część na podstawie relacji kobiet pozostawionych w Archiwum Związku

Aleksandra Rybińska

ROLA, DZIAŁALNOŚĆ I ZNACZENIE KOBIET W ARMII KRAJOWEJ

BIOGRAFIE REGIONU ŁÓDZKIEGO

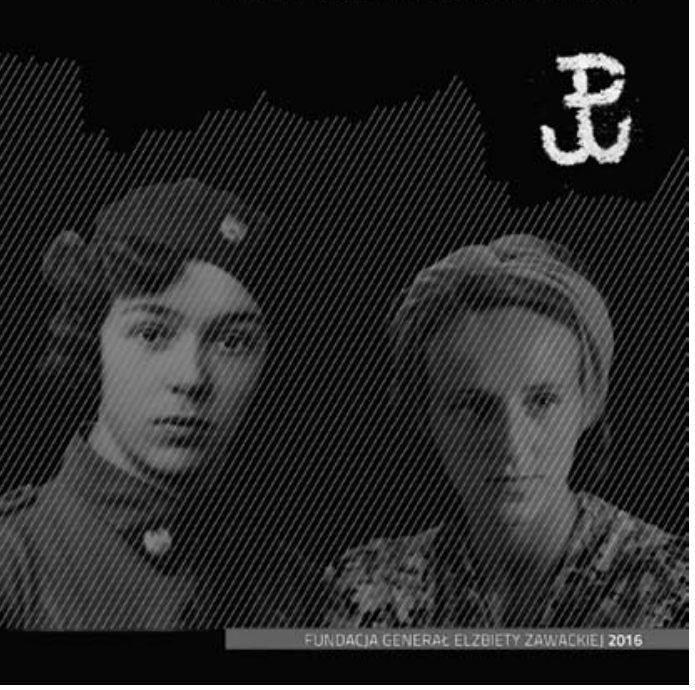

Biuletyn R. XXVIII: 2016 (66) 
Kombatantów RP i Byłych Więźniów Politycznych w Łodzi. Większość kobiet mieszkała w Łodzi lub w okolicy przed lub po wojnie, wszystkie należały do AK i bardzo aktywnie ją wspierały. We wstępie czytamy: "Za pośrednictwem biogramów tych kilkunastu kobiet autorka pragnie przybliżyć czytelnikowi, jak odmienne były losy kobiet w trakcie działań wojennych, a także zwrócić szczególną uwagę na rolę jednostek - kobiet $\mathrm{i}$ ich znaczenie w AK".

Książka powstała na podstawie pracy magisterskiej napisanej pod kierunkiem dr. hab. Przemysława Waingertnera, prof. Uniwersytetu Łódzkiego.

Książka zawiera streszczenia w języku angielskim i niemieckim, indeksy osób i nazw geograficznych oraz bibliografię. Jest także bogato ilustrowana.

Książka dostępna jest za darmo, w postaci pliku PDF - do pobrania pod adresem: http://zawacka.pl/ksiegarnia

Dorota Kromp

W 2016 r. nakładem Biblioteki Fundacji ukazały się także anglojęzyczne wersje dwóch książek:

Bogdan Chrzanowski, Delegatura Rzadu RP na Kraj na Pomorzu. Nieznane karty $z$ frontu walki cywilnej podczas okupacji niemieckiej i po jej zakończeniu, Biblioteka Fundacji "Archiwum Pomorskie Armii Krajowej”, Torun, 2011, ss. 416 (omówienie Biuletyn FGEZ R. XXIV: 2012, Nr 62) - tytuł angielski: Government Delegation for Poland in Pomerania. Unknown facts from the civilian front during and after the German occupation.

Andrzej Gąsiorowski, Komenda Obrońców Polski: Okręg Pomorze, Biblioteka Fundacji „Archiwum Pomorskie Armii Krajowej”, Torun 2012, ss. 235 (omówienie Biuletyn FGEZ R. XXVII: 2015, Nr 65) - tytuł angielski: Headquarters of the Defenders of Poland (KOP). The Pomeranian District Division.

Książki są dostępne za darmo w postaci pliku PDF - do pobrania pod adresem: http://zawacka.pl/ksiegarnia

Dorota Kromp 